Open Access

\title{
Complete genome sequence of bacteriophage P8625, the first lytic phage that infects Verrucomicrobia
}

\author{
Ahyoung Choi, Ilnam Kang, Seung-Jo Yang and Jang-Cheon Cho*
}

\begin{abstract}
Bacteriophage P8625 is a lytic bacteriophage that infects the verrucomicrobial strain IMCC8625, a marine bacterium affiliated with Verrucomicrobia subdivision 4. Both the bacteriophage and the host bacterial strain were isolated from surface seawater samples collected off the east coast of Korea. The phage particle has an icosahedral capsid with a diameter of $\sim 47 \mathrm{~nm}$ and a long tail of $\sim 75 \mathrm{~nm}$ in length, showing the distinctive morphology of the Siphoviridae family. The complete genome sequence of phage P8625 is 32,894 bp long with $51.0 \% \mathrm{G}+\mathrm{C}$ content. This is the first report of the complete genome sequence of a lytic phage that infects the Verrucomicrobia, for which the name "verrucophage" is proposed.
\end{abstract}

Keywords: Verrucophage, Verrucomicrobia bacteriophage, Genome, Marine phage, Siphoviridae

\section{Introduction}

Marine viruses are the most abundant biological components in the ocean, with $\sim 10^{7}$ virus-like particles per milliliter in surface seawater [1-3]. Marine bacteriophages lyse specific bacterial hosts, controlling bacterial abundance and diversity and influencing biogeochemical cycles, which makes the study of marine viruses ecologically important $[2,4,5]$. Recent metagenomic studies have demonstrated immense genetic diversity among marine viruses [6-8]. However, these studies had difficulty in the phylogenetic interpretation of metagenomes due to the shortage of genetic data from representative marine viral isolates [7, 9]. Therefore, isolation of bacteriophages is also important for a better understanding of marine virome data $[10,11]$.

Bacterial members of the phylum Verrucomicrobia are distributed widely in the ocean environment, albeit in low densities [12]. Based on 16S rRNA gene sequence analyses, the phylum Verrucomicrobia was found to comprise an average of $2 \%$ of the water column and $1.4 \%$ of the sediment bacterial population [12]. Compared to marine environments, in terrestrial ecosystems such as soil environments, the phylum Verrucomicrobia is highly abundant and often exceed $20 \%$ of the total rRNA gene sequences

\footnotetext{
* Correspondence: chojc@inha.ac.kr

* Correspondence: chojc@inha.ac.kr
Department of Biological Sciences, Inha University, Incheon 402-751, Republic of Korea
}

[13]. To our knowledge, however, no lytic phage infecting verrucomicrobial strains has been reported [14], perhaps largely due to the scarcity of bacterial hosts. Interestingly, a few recent studies based on fosmid sequencing or single cell genomics have hinted at the presence of verrucomicrobial phages in marine environments [15-17].

In this study, we report the isolation and genomic characterization of bacteriophage P8625, a novel marine siphovirus that infects the marine bacterial strain IMCC8625. Because the bacterial strain belongs to the class Opitutae [18] of the phylum Verrucomicrobia, phage P8625, isolated off the east coast of Korea, is egarded as the first isolated lytic phage of the Verrucomi-

\section{Organism information}

Bacterial strain IMCC8625 was isolated using highthroughput cultivation based on dilution to extinction [19], during a survey of microbial assemblages inhabiting coastal seawater of the East Sea. A comparison of $16 \mathrm{~S}$ rRNA gene sequences indicated that strain IMCC8625 was closely related to Coraliomargarita akajimensis DSM $45221^{\mathrm{T}}$ (95.4\% similarity), a marine verrucomicrobial strain $[20,21]$. Strain IMCC8625 was used as the bacterial 
host for the screening of marine lytic bacteriophages, which resulted in the isolation of verrucophage P8625.

Verrucophage P8625 was isolated from a surface seawater sample collected off the east coast of South Korea, in the East Sea (Sea of Japan). It is a lytic phage, forming plaques with a diameter of 1 to $2 \mathrm{~mm}$ after 5 days of infection of strain IMCC8625. Transmission electron microscopy of purified phage particles showed that P8625 had an icosahedral capsid approximately $47 \mathrm{~nm}$ in diameter and a long tail $71 \sim 75 \mathrm{~nm}$ in length (Fig. 1a). Bacteriophage P8625 attaches itself to and infects the host cell (Fig. 1b). The tail appears to be long and non-contractile, which is typically seen in members of the Siphoviridae family [22]. The genome of P8625 is comprised of dsDNA with a length of $32,894 \mathrm{bp}$ and $51.0 \% \mathrm{G}+\mathrm{C}$ content. The morphological evidence (Fig. 1), together with the dsDNA genome, has led to the tentative classification of P8625 as a member of the Siphoviridae family, with an unassigned genus. A summary of the isolation and general phylogenetic features of phage P8625 are shown in Table 1.

\section{Genome sequencing information Genome project history}

Bacteriophage P8625 was selected for genome sequencing because of its importance to understand bacteriophages infecting members of the Verrucomicrobia that are known to play crucial ecological roles in the ocean [23]. This bacteriophage that was shown to infect bacterium IMCC8625 in this study is the first lytic phage infecting Verrucomicrobia. This genome sequence has been submitted to GenBank, and the project information is also available in GOLD. A summary of the project information is shown in Table 2.

\section{Growth conditions and genomic DNA preparation}

Verrucophage P8625 was isolated from a surface seawater sample collected at the station where the host strain IMCC8625 had been isolated, using the standard plaque assay after being enriched with the host. For the enrichment, the seawater sample was filtered using a $0.22-\mu \mathrm{m}$ polyethersulfone membrane filter (Durapore, Millipore) to remove bacterial particles. To $400 \mathrm{ml}$ filtered seawater, $100 \mathrm{ml}$ of $5 \times \mathrm{R} 2 \mathrm{~A}$ broth (BD Difco) and $30 \mathrm{ml}$ of exponentially grown IMCC 8625 culture were added. During incubation of this enrichment culture at $20{ }^{\circ} \mathrm{C}$ for 2 weeks, $10 \mathrm{ml}$ of the culture was removed and treated with $2 \mathrm{ml}$ of chloroform at 3 days interval. After centrifugation of chloroform-treated cultures to remove bacterial debris, bacteria-free supernatants were used for double agar overlay plaque assay. From an isolated plaque on the final assay plate, a single strain of phage was established and designated P8625.

The purification of phage DNA followed the method outlined in Molecular Cloning: A Laboratory Manual [24] with minor modifications. Approximately 21 of phage lysates were prepared for DNA purification. DNase I and RNase A were added at a final concentration of $1 \mu \mathrm{g}$ per $\mathrm{ml}$. Then, $116.9 \mathrm{~g}$ of $\mathrm{NaCl}$ was dissolved in the lysates and cooled at $4{ }^{\circ} \mathrm{C}$. After about $1 \mathrm{~h}$, the mixed lysates were centrifuged at $10,000 \times \mathrm{g}$ for $30 \mathrm{~min}$ at $4{ }^{\circ} \mathrm{C}$ to remove the debris. Phage particles in the supernatant were precipitated with $10 \%(w / v)$ PEG 8000 (Sigma-Aldrich). After an overnight incubation at $4{ }^{\circ} \mathrm{C}$, the mixture was pelleted at $10,000 \times \mathrm{g}$ for $25 \mathrm{~min}$ at $4{ }^{\circ} \mathrm{C}$ and the pellet was gently resuspended in $2 \mathrm{ml}$ $\mathrm{SM}$ buffer $(50 \mathrm{mM}$ Tris- $\mathrm{HCl}, \mathrm{pH} 7.5 ; 100 \mathrm{mM} \mathrm{NaCl}$; $10 \mathrm{mM} \mathrm{MgSO}_{4} \cdot 7 \mathrm{H}_{2} \mathrm{O} ; 0.01 \%$ gelatin). PEG was extracted by treatment with an equal volume of chloroform. The phages were then ultracentrifuged at $246,000 \times \mathrm{g}$ for $2 \mathrm{~h}$ at $4{ }^{\circ} \mathrm{C}$ in an L-90 K ultracentrifuge (Beckman) with an $\mathrm{SW} 55 \mathrm{Ti}$ rotor. Pelleted phage particles were resuspended with $100 \mu \mathrm{l}$ of SM buffer overnight at $4{ }^{\circ} \mathrm{C}$, and the purified phages were stored in the dark at $4{ }^{\circ} \mathrm{C}$. The genomic DNA of P8625 was extracted using a silica based spin column (Qiagen DNeasy Blood and Tissue Kit) according to the manufacturer's instructions.

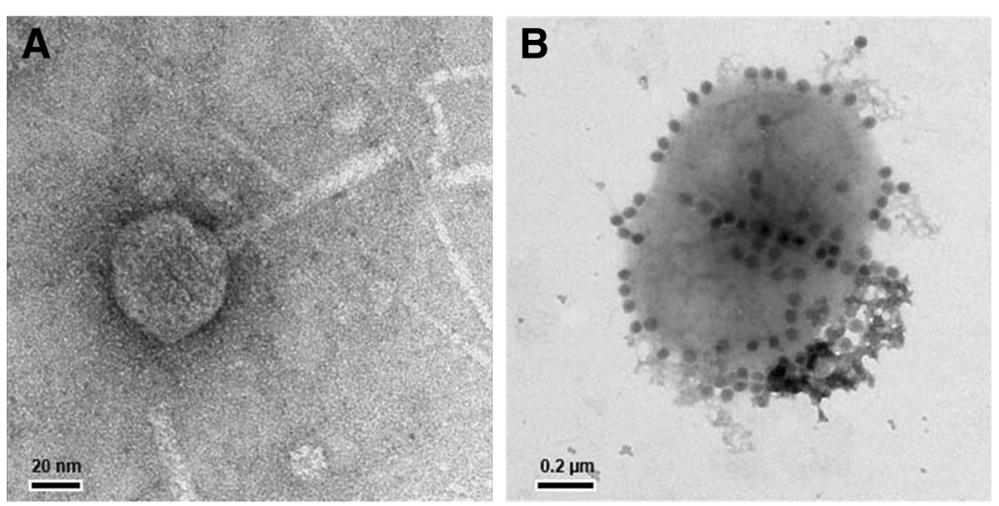

Fig. 1 Transmission electron micrographs of verrucophage P8625 particles. a A single particle of P8625, b Bacteriophage particles attached to a host cell 
Table 1 Classification and general features of verrucophage P8625 according to the MIGS recommendation

\begin{tabular}{|c|c|c|c|}
\hline MIGS ID & Property & Term & Evidence code ${ }^{\mathrm{a}}$ \\
\hline & Classification & Domain: viruses, dsDNA viruses, no RNA stage & TAS [39] \\
\hline & & Phylum: unassigned & \\
\hline & & Class: unassigned & \\
\hline & & Order: Caudovirales & TAS [39] \\
\hline & & Family: Siphoviridae & TAS [39] \\
\hline & & Genus: unassigned & \\
\hline & & Species: unassigned & \\
\hline & & Strain: P8625 & \\
\hline & Particle shape & Icosahedral capsid with a long noncontractile tail & IDA \\
\hline MIGS-6 & Habitat & Marine surface water, coastal & IDA \\
\hline MIGS-15 & Biotic relationship & Intracellular parasite of Verrucomicrobia strain IMCC8625 & IDA \\
\hline MIGS-14 & Pathogenicity & Lytic virus of strain IMCC8625 & IDA \\
\hline MIGS-4 & Geographic location & East Sea (Sea of Japan), Sokcho, South Korea & IDA \\
\hline MIGS-5 & Sample collection & October 2, 2013 & IDA \\
\hline MIGS-4.1 & Latitude & $38^{\circ} 14^{\prime} 12^{\prime \prime} N$ & IDA \\
\hline MIGS-4.2 & Longitude & $128^{\circ} 40^{\prime} 59^{\prime \prime} \mathrm{E}$ & IDA \\
\hline MIGS-4.4 & Altitude & - & IDA \\
\hline
\end{tabular}

${ }^{a}$ Evidence codes - IDA: Inferred from Direct Assay; TAS: Traceable Author Statement. The evidence codes are from the Gene Ontology project [40]

\section{Genome sequencing and assembly}

The genomic DNA of P8625 was sequenced at ChunLab, Inc. using an Illumina Miseq system with $2 \times 300$ bp paired-end reads. Assembly of the resulting reads was performed using SPAdes version 3.1.1 [25]. The Illumina platform provided $3085 \times$ fold coverage of the genome. The genome was assembled into one contig through PCR-based gap closing.

Table 2 Project information

\begin{tabular}{lll}
\hline MIGS ID & Property & Term \\
\hline MIGS-31 & Finishing quality & Finished \\
MIGS-28 & Libraries used & $\begin{array}{l}\text { One paired-end } \\
\text { Illumina library }\end{array}$ \\
MIGS-29 & Sequencing platforms & Illumina MiSeq \\
MIGS-31.2 & Fold coverage & $3085 \times$ \\
MIGS-30 & Assemblers & SPAdes version 3.1.1 \\
MIGS-32 & Gene calling method & RAST version 2.0, \\
& & GeneMark.hmm, \\
& and GLIMMER \\
& GenBank ID & KP792622 \\
& GenBank Date of Release & April 5, 2015 \\
& GOLD ID & Gp0111340 \\
& BIOPROJECT & NA \\
& Source Material Identifier & NA \\
MIGS-13 & Project relevance & Diversity of marine \\
& & bacteriophage \\
\hline
\end{tabular}

\section{Genome annotation}

The prediction of genes in the genome was performed using a combination of three gene calling methods: the RAST server [26], Genemark.hmm 3.25 [27], and GLIMMER version 3.02 [28]. Assignment of protein function to ORFs was performed manually using BLASTp against the NCBI nonredundant database

Table 3 Genome statistics

\begin{tabular}{llr}
\hline Attribute & Value & \% of Total \\
\hline Genome size (bp) & 32,894 & 100.00 \\
DNA coding (bp) & 31,525 & 95.84 \\
DNA G + C (bp) & 16,765 & 50.97 \\
DNA scaffolds & 1 & 100.00 \\
Total genes & 52 & 100.00 \\
Protein coding genes & 52 & 100.00 \\
RNA genes & 0 & 0.00 \\
Pseudo genes & 0 & 0.00 \\
Genes in internal clusters & 0 & 0.00 \\
Genes with function prediction & 13 & 25.00 \\
Genes assigned to COGs & 8 & 15.38 \\
Genes with Pfam domains & 13 & 25.00 \\
Genes with signal peptides & 0 & 0.00 \\
Genes with transmembrane helices & 4 & 7.69 \\
CRISPR repeats & 0 & 0.00 \\
\hline
\end{tabular}

The total is based on the total number of protein-coding genes in the annotated genome 


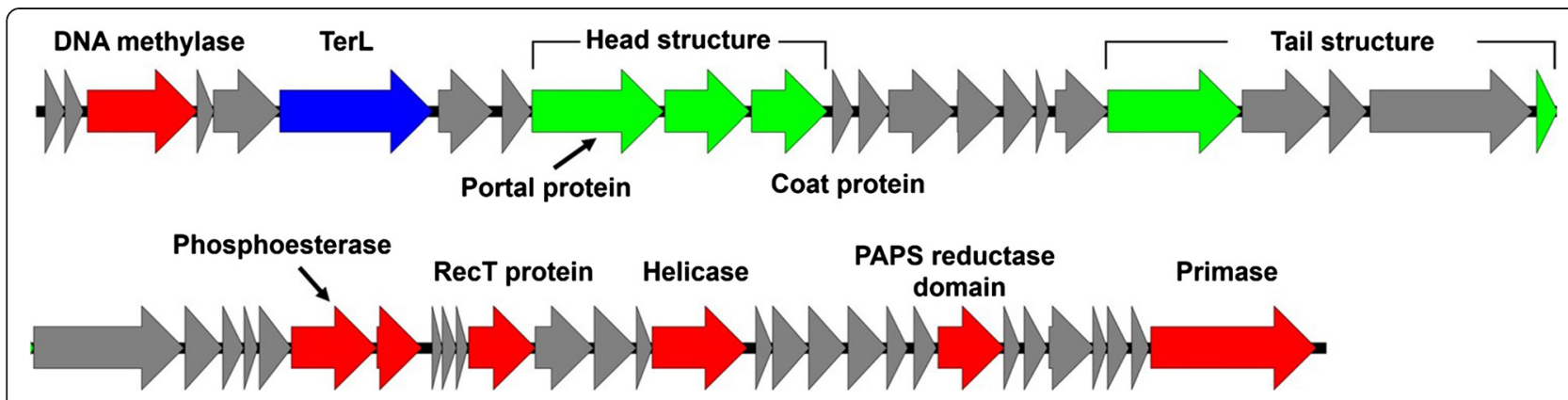

Fig. 2 Genome map of verrucophage P8625. Total length of the genome is 32,894 bp and functional modules are indicated by color (Green: structure; Blue: DNA packaging; Red: DNA replication and metabolism; Gray: hypothetical proteins)

and RPS-BLAST or HMMER search against the COG database [29], Pfam database [30], and TIGRFam database [31]. InterProScan was also used [32]. Search results were combined to assign a putative function for each predicted protein. TMHMM [33] and SignalP [34] were used to predict transmembrane helices and signal peptides, respectively.

\section{Genome properties}

The properties and statistics of the genome are summarized in Table 3. The genome of P8625 was assembled as a 32,894 bp dsDNA, with a $\mathrm{G}+\mathrm{C}$ content of $51.0 \%$. In total, 52 putative CDSs were predicted in the phage genome (Fig. 2). Of the 52 predicted protein-coding genes, 13 genes were assigned putative

Table 4 Number of genes associated with general COG functional categories

\begin{tabular}{|c|c|c|c|}
\hline Code & Value & $\%$ of Total ${ }^{a}$ & Description \\
\hline J & 0 & 0.00 & Translation, ribosomal structure and biogenesis \\
\hline A & 0 & 0.00 & RNA processing and modification \\
\hline K & 0 & 0.00 & Transcription \\
\hline L & 2 & 3.85 & Replication, recombination and repair \\
\hline B & 0 & 0.00 & Chromatin structure and dynamics \\
\hline $\mathrm{D}$ & 0 & 0.00 & Cell cycle control, cell division, and chromosome partitioning \\
\hline V & 0 & 0.00 & Defense mechanisms \\
\hline T & 0 & 0.00 & Signal transduction mechanisms \\
\hline M & 0 & 0.00 & Cell wall/membrane biogenesis \\
\hline $\mathrm{N}$ & 0 & 0.00 & Cell motility \\
\hline$U$ & 0 & 0.00 & Intracellular trafficking and secretion \\
\hline O & 1 & 1.92 & Posttranslational modification, protein turnover, and chaperones \\
\hline C & 0 & 0.00 & Energy production and conversion \\
\hline G & 0 & 0.00 & Carbohydrate transport and metabolism \\
\hline E & 1 & 1.92 & Amino acid transport and metabolism \\
\hline $\mathrm{F}$ & 0 & 0.00 & Nucleotide transport and metabolism \\
\hline $\mathrm{H}$ & 0 & 0.00 & Coenzyme transport and metabolism \\
\hline 1 & 0 & 0.00 & Lipid transport and metabolism \\
\hline P & 0 & 0.00 & Inorganic ion transport and metabolism \\
\hline Q & 0 & 0.00 & Secondary metabolites biosynthesis, transport and catabolism \\
\hline $\mathrm{R}$ & 0 & 0.00 & General function prediction only \\
\hline S & 0 & 0.00 & Function unknown \\
\hline$x$ & 2 & 3.85 & Phage terminase and bacteriophage capsid protein \\
\hline- & 44 & 84.62 & Not in COGs \\
\hline
\end{tabular}

${ }^{a}$ The total is based on the total number of protein coding genes in the genome 
functions, whereas the remaining genes were annotated as coding for hypothetical proteins. Four proteins with transmembrane helices were identified, but signal peptides were not detected in any protein. The distribution of genes into COG functional categories is presented in Table 4.

\section{Insights from the genome sequence}

When all 52 CDSs predicted from the P8625 genome were subjected to functional annotation based mainly on a conserved domain/motif search, only $13 \mathrm{CDSs}$ were found to have specific functions. These functions were related to head and tail assembly, DNA packaging, or DNA replication and metabolism (Fig. 2 and Additional file 1: Table S1). Head and tail structural proteins were similar to those of the Siphoviridae family, while some proteins involved in DNA packaging and DNA replication/metabolism were similar to those of the Myoviridae family, suggesting mosaicism of the genome. The genome contained a putative RecT protein (CDS34) and a protein containing a PAPS reductase domain (CDS45) (Additional file 1: Table S1 and Fig. 2). RecT protein is involved in recombination repair of DNA [35], and homologs of RecT have been found in many phages [36]. The function of the protein containing the PAPS reductase domain (CDS45) is unclear. Although we cannot exclude the possibility of this protein being involved in sulfate metabolism, the location of this protein in the genome (Fig. 2) and the affiliation of PAPS reductase domain with the adenine nucleotide alpha hydrolase superfamily (cl00292) suggest that this protein could play a role in DNA metabolism.

A TerL, a commonly-used viral phylogenetic marker $[37,38]$, was predicted in the phage P8625 genome and used for phylogenetic analyses together with other representative tailed phages and Verrucomicrobia prophages (Fig. 3). In the resulting phylogenetic tree, the terminases from P8625 and Verrucomicrobia prophages formed a robust cluster supported by high bootstrap values (Fig. 3), which suggested that P8625 has a strong

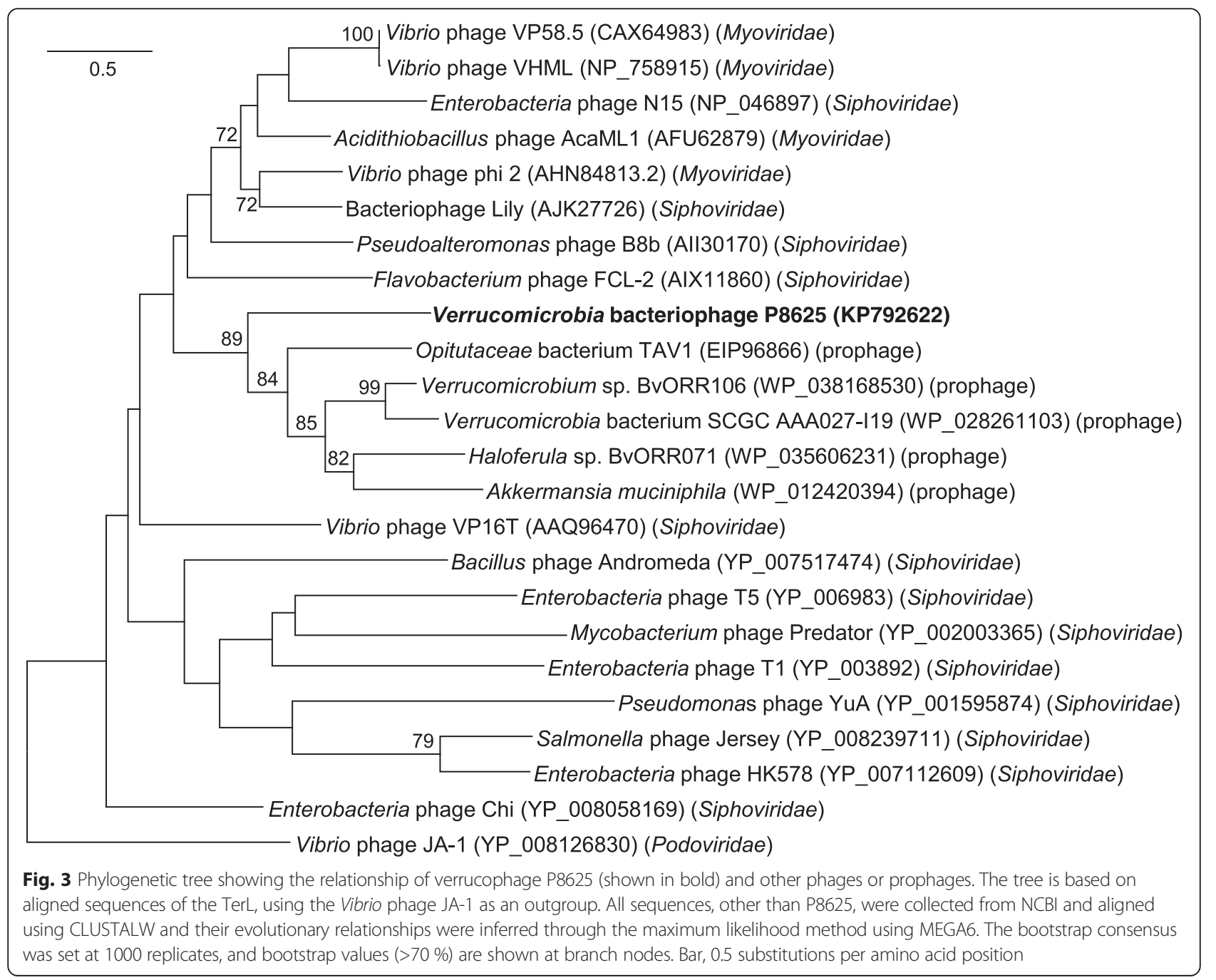


relationship with Verrucomicrobia prophages, without a clear affiliation with any of the three families of dsDNA tailed phages.

Several proteins predicted from the P8625 genome, including DNA methylase (CDS3), TerL (CDS6), and head structure proteins (CDS9-11), were similar to proteins annotated from a short $(\sim 14 \mathrm{~kb})$ contig of a verrucomicrobial single cell genome SCGC AAA027-I19. This contig might have originated from a prophage in the host genome or might have been derived from a lytic phage during an infection cycle when the host cell was selected for multiple displacement amplification.

\section{Conclusions}

The virulent verrucophage P8625, a siphovirus isolated from seawater in the East Sea, represents the first identification of a Verrucomicrobia phage. The dsDNA genome of P8625 was 32,894 bp long, with a $51.0 \% \mathrm{G}+\mathrm{C}$ content. Among the 52 protein-encoding genes predicted in the genome, only 13 genes were functionally annotated, while the remaining $75 \%$ of the genes were annotated as encoding hypothetical proteins. Verrucophage P8625 and its genome sequence can improve our understanding of the interaction of marine verrucomicrobial strains and their phages.

\section{Additional file}

Additional file 1: Table S1. Verrucophage P8625 gene annotation. (PDF $77 \mathrm{~kb}$ )

\section{Abbreviations}

PEG: Polyethylene glycol; PAPS: Phosphoadenosine phosphosulphate; TerL: Terminase large subunit.

\section{Competing interests}

The authors declare that they have no competing interests.

\section{Authors' contributions}

S-JY isolated the host, Verrucomicrobia strain IMCC8625, and collected seawater samples. AC performed laboratory experiments, drafted the manuscript, and analyzed the data. IK and J-CC together organized this study and wrote the manuscript. All authors read and approved the final manuscript

\section{Acknowledgements}

This study was supported by a grant from the Marine Biotechnology Program (to J-CC, PJT200620, Genome Analysis of Marine Organisms and Development of Functional Applications) funded by the Ministry of Oceans and Fisheries, Korea, and also by the Basic Science Research Program through the National Research Foundation of Korea (NRF) funded by the Ministry of Education (to IK, NRF-2013R1A1A2063660).

Received: 9 April 2015 Accepted: 29 October 2015

Published online: 11 November 2015

\section{References}

1. Suttle CA. Viruses in the sea. Nature. 2005;437:356-61.

2. Fuhrman JA. Marine viruses and their biogeochemical and ecological effects. Nature. 1999;399:541-8

3. Breitbart M. Marine viruses: truth or dare. Ann Rev Mar Sci. 2012;4:425-48.
4. Suttle CA. Marine viruses-major players in the global ecosystem. Nat Rev Microbiol. 2007:5:801-12.

5. Weinbauer MG. Ecology of prokaryotic viruses. FEMS Microbiol Rev. 2004;28:127-81.

6. Ma YF, Allen LZ, Palenik B. Diversity and genome dynamics of marine cyanophages using metagenomic analyses. Env Microbiol Rep. 2014;6:583-94.

7. Angly FE, Felts B, Breitbart M, Salamon P, Edwards RA, Carlson C, et al. The marine viromes of four oceanic regions. PLoS Biol. 2006:4:e368.

8. Hurwitz BL, Sullivan MB. The Pacific Ocean Virome (POV): a marine viral metagenomic dataset and associated protein clusters for quantitative viral ecology. PLoS ONE. 2013;8:e57355.

9. Williamson SJ, Allen LZ, Lorenzi HA, Fadrosh DW, Brami D, Thiagarajan M, et al. Metagenomic exploration of viruses throughout the Indian Ocean. PLOS ONE. 2012;7:e42047.

10. Kang I, Oh HM, Kang D, Cho JC. Genome of a SAR116 bacteriophage shows the prevalence of this phage type in the oceans. Proc Natl Acad Sci U S A. 2013;110:12343-8.

11. Zhao Y, Temperton B, Thrash JC, Schwalbach MS, Vergin KL, Landry ZC, et al. Abundant SAR11 viruses in the ocean. Nature. 2013;494:357-60.

12. Freitas S, Hatosy S, Fuhrman JA, Huse SM, Welch DB, Sogin ML, et al. Global distribution and diversity of marine Verrucomicrobia. ISME J. 2012;6:1499-505.

13. Bergmann GT, Bates ST, Eilers KG, Lauber CL, Caporaso JG, Walters WA, et al. The under-recognized dominance of Verrucomicrobia in soil bacterial communities. Soil Biol Biochem. 2011;43:1450-5.

14. Wommack KE, Nasko DJ, Chopyk J, Sakowski EG. Counts and sequences, observations that continue to change our understanding of viruses in nature. J Microbiol. 2015;53:181-92.

15. Mizuno CM, Rodriguez-Valera F, Kimes NE, Ghai R. Expanding the marine virosphere using metagenomics. PLoS Genet. 2013;9, e1003987.

16. Rodriguez-Valera F, Mizuno CM, Ghai R. Tales from a thousand and one phages. Bacteriophage. 2014;4:e28265.

17. Swan BK, Tupper B, Sczyrba A, Lauro FM, Martinez-Garcia M, Gonzalez JM, et al. Prevalent genome streamlining and latitudinal divergence of planktonic bacteria in the surface ocean. Proc Natl Acad Sci U S A. 2013;110:11463-8.

18. Choo YJ, Lee K, Song J, Cho JC. Puniceicoccus vermicola gen. nov., sp. nov., a novel marine bacterium, and description of Puniceicoccaceae fam. nov., Puniceicoccales ord. nov., Opitutaceae fam. nov., Opitutales ord. nov. and Opitutae classis nov. in the phylum 'Verrucomicrobia'. Int J Syst Evol Microbiol. 2007:57:532-7.

19. Connon SA, Giovannoni SJ. High-throughput methods for culturing microorganisms in very-low-nutrient media yield diverse new marine isolates. Appl Environ Microbiol. 2002;68:3878-85

20. Yoon J, Yasumoto-Hirose M, Katsuta A, Sekiguchi H, Matsuda S, Kasai H, et al. Coraliomargarita akajimensis gen. nov., sp. nov., a novel member of the phylum 'Verrucomicrobia' isolated from seawater in Japan. Int I Syst Evol Microbiol. 2007;57:959-63.

21. Mavromatis K, Abt B, Brambilla E, Lapidus A, Copeland A, Deshpande S, et al. Complete genome sequence of Coraliomargarita akajimensis type strain (04OKA010-24). Stand Genomic Sci. 2010;2:290-9.

22. Plisson C, White HE, Auzat I, Zafarani A, Sao-Jose C, Lhuillier S, et al. Structure of bacteriophage SPP1 tail reveals trigger for DNA ejection. EMBO J. 2007:26:3720-8.

23. Martinez-Garcia M, Brazel DM, Swan BK, Arnosti C, Chain PS, Reitenga KG, et al. Capturing single cell genomes of active polysaccharide degraders: an unexpected contribution of Verrucomicrobia. PLoS ONE. 2012;7, e35314.

24. Green MR, Sambrook J. Molecular cloning: a laboratory manual. New York: Cold Spring Harbor Laboratory Press; 2012.

25. Bankevich A, Nurk S, Antipov D, Gurevich AA, Dvorkin M, Kulikov AS, et al. SPAdes: a new genome assembly algorithm and its applications to single-cell sequencing. J Comput Biol. 2012;19:455-77.

26. Aziz RK, Bartels D, Best AA, DeJongh M, Disz T, Edwards RA, et al. The RAST Server: rapid annotations using subsystems technology. BMC Genomics. 2008;9:75.

27. Besemer J, Borodovsky M. Heuristic approach to deriving models for gene finding. Nucleic Acids Res. 1999;27:3911-20.

28. Delcher AL, Bratke KA, Powers EC, Salzberg SL. Identifying bacterial genes and endosymbiont DNA with Glimmer. Bioinformatics. 2007;23:673-9.

29. Tatusov RL, Galperin MY, Natale DA, Koonin EV. The COG database: a tool for genome-scale analysis of protein functions and evolution. Nucleic Acids Res. 2000;28:33-6.

30. Punta M, Coggill PC, Eberhardt RY, Mistry J, Tate J, Boursnell C, et al. The Pfam protein families database. Nucleic Acids Res. 2012;40:D290-301. 
31. Haft DH, Selengut JD, Richter RA, Harkins D, Basu MK, Beck E. TIGRFAMs and Genome Properties in 2013. Nucleic Acids Res. 2013;41:D387-95.

32. Jones $P$, Binns $D$, Chang HY, Fraser M, Li W, McAnulla C, et al. InterProScan 5 : genome-scale protein function classification. Bioinformatics. 2014;30:1236-40.

33. Krogh A, Larsson B, von Heijne G, Sonnhammer EL. Predicting transmembrane protein topology with a hidden Markov model: application to complete genomes. J Mol Biol. 2001;305:567-80.

34. Petersen TN, Brunak S, von Heijne G, Nielsen H. SignalP 4.0: discriminating signal peptides from transmembrane regions. Nat Methods. 2011;8:785-6.

35. Hall SD, Kolodner RD. Homologous pairing and strand exchange promoted by the Escherichia coli RecT protein. Proc Natl Acad Sci U S A. 1994;91:3205-9.

36. Iyer LM, Koonin EV, Aravind L. Classification and evolutionary history of the single-strand annealing proteins, RecT, Redbeta, ERF and RAD52. BMC Genomics. 2002;3:8.

37. Casjens SR, Gilcrease EB, Winn-Stapley DA, Schicklmaier P, Schmieger $H$, Pedulla ML, et al. The generalized transducing Salmonella bacteriophage ES18: complete genome sequence and DNA packaging strategy. J Bacteriol. 2005;187:1091-104.

38. Sullivan MB, Krastins B, Hughes JL, Kelly L, Chase M, Sarracino D, et al. The genome and structural proteome of an ocean siphovirus: a new window into the cyanobacterial 'mobilome'. Environ Microbiol. 2009;11:2935-51.

39. King AMQ, Adams MJ, Carstens EB, Lefkowitz EJ. Virus taxonomy: classification and nomenclature of viruses: ninth report of the international committee on taxonomy of viruses. San Diego: Elsevier; 2012. p. 855-80.

40. Ashburner M, Ball CA, Blake JA, Botstein D, Butler H, Cherry JM, et al. Gene ontology: tool for the unification of biology. The Gene Ontology Consortium. Nat Genet. 2000;25:25-9.

\section{Submit your next manuscript to BioMed Central and take full advantage of:}

- Convenient online submission

- Thorough peer review

- No space constraints or color figure charges

- Immediate publication on acceptance

- Inclusion in PubMed, CAS, Scopus and Google Scholar

- Research which is freely available for redistribution 